\title{
Erratum zu: Stochastische Leistungsanalyse von Lagersystemen
}

\section{Erratum zu:}

\section{A. Heßler, Stochastische Leistungsanalyse von Lagersystemen, https://doi.org/10.1007/978-3-658-31811-6}

Aufgrund eines technischen Problems seitens des Verlegers wurde dieses Buch zunächst mit dem Copyright Jahr 2021 veröffentlicht. Das Copyright Jahr wurde auf 2020 korrigiert. 